\title{
Pengembangan Media Koper Perilaku (Koperku) untuk Mengenalkan Perilaku Disiplin Anak Usia 4-5 Tahun
}

\author{
Sarah Putri Syafira ${ }^{1}$, Hukmi $^{2}$, Ria Novianti ${ }^{3}$ \\ $(1,2,3)$ Pendidikan Guru Pendidikan Anak Usia Dini, Universitas Riau
}

$\bowtie$ Corresponding author

[sarahputrisyafira0701@gmaKil.com]

\begin{abstract}
Abstrak
Penelitian pengembangan ini betujuan untuk menghasilkan media Koperku. Media Koperku merupakan media yang dapat membantu anak untuk lebih mengenal perilaku disiplin dengan cara yang menyenangkan dan mudah diterima oleh anak. Untuk mengembangkan media Koper Perilaku (KOPERKU) sebagai Alat Permainan Edukatif (APE) yang layak untuk anak didik usia 4-5 tahun. Untuk mengetahui kelayakan media Koper Perilaku (KOPERKU) oleh validator dalam mengenalkan perilaku disiplin anak usia usia 4-5 tahun. Penelitian ini merupakan penelitian R\&D (Research and Development) dengan menggunakan prosedur pengembangan menurut Bord and Gall. Dengan langkah penelitian berupa analisis potensi dan masalah, pengumpulan data, desain produk, validasi desain, validasi produk, validasi desain, revisi produk. Jenis data yang dihasilkan dan dianalisis pada penelitian ini adalah deskriptif kuantitatif. Berdasarkan hasil penelitian yang telah dilakukan dapat disimpulkan bahwa media Koperku dinyatakan "Layak" oleh validator ahli materi, ahli media dan ahli pendidik dengan serangkaian uji validasi sehingga layak untuk mengenalkan kepada anak usia 4-5 tahun dalam berperilaku disiplin. Hal ini dibuktikan dari hasil penilaian produk yang dinilai oleh validator ahli materi, ahli media dan ahli pendidik yaitu $(2,8)$.
\end{abstract}

Kata Kunci: Koperku; Perilaku Disiplin; Anak Usia 4-5 Tahun

\begin{abstract}
This development research aims to produce media Koperku. Media Koperku is a medium that can help children to learn disciplined behavior in a way that is fun and easily accepted by children. Developing the Behavior Suitcase media (KOPERKU) as a suitable educational game tool (APE) for students aged 4-5 years. Investigation of the feasibility of the Copper Behavior media (KOPERKU) by the validator in the introduction of disciplinary behavior for children aged 4-5 years. This research is an R\&D (Research and Development) research according to the development procedure according to Bord and Gall. With research steps in the form of potential and problem analysis, data collection, product design, design validation, product validation, design validation, product revision. The type of data generated and analyzed in this study is descriptive quantitative. Based on the results of the research done, it can be concluded that the Koperku media are declared "good" by materials experts validators, media experts and educators with a series of validation tests, so that it is feasible to introduce children as young as 4 years old. . -5 years in disciplined behavior. This is evidenced by the results of product reviews assessed by materials experts, media experts and educators, namely (2.8).
\end{abstract}

Keyword: Koperku; Discipline Behavior; Children from 4-5

\section{PENDAHULUAN}

Disiplin adalah metode untuk membentuk karakter anak dan mengajari mereka untuk melatih kontrol diri dan melakukan perilaku yang dapat diterima masyarakat (Iriani Indri Hapsari, 2016). Menurut Kompri, 2016 (dalam Amna, 2017) Perilaku disiplin adalah ranah afektif. Afektif merupakan kemampuan yang mengutamakan perasaan, emosi dan reaksi-reaksi yang berbeda dengan penalaran yang terdiri dari kategori penerimaan, partisipasi, penilaian sikap, organisasi dan pembentukan pola hidup. Dalam hal ini yang dapat dilakukan untuk menstimulasi anak berperilaku disiplin adalah dengan cara pengenalan dan pembiasaan.

Kedisiplinan anak perlu diperhatikan dan dikembangkan, karena disiplin mampu membentuk anak lebih memaksimalkan perannya dalam hidup bermasyarakat. Mengajarkan disiplin kepada anak sejak usia dini, sama halnya melatih anak agar dapat bertanggung jawab dimasa yang akan datang. Apabila disiplin sudah diajarkan sejak dini kepada anak melalui lingkungan keluarga, maka sangat mudah bagi anak untuk mengikuti dan menyesuaikan peraturan yang berlaku dilingkungan lain (Wantah, 2005). 
Salah satu cara yang dapat dilakukan untuk membiasakan maupun mempraktekkan perilaku disiplin kepada anak adalah dengan cara membangun dan menegakkan konsekuensi dengan cara yang mendidik, saat ini banyak kasus kekerasan yang terjadi pada anak dengan alasan untuk mendisiplinkan anak. Dengan adanya kekerasan yang dialami oleh anak, hal ini akan berpengaruh pada psikologisnya secara berkepanjangan. Penanaman perilaku disiplin tidak seharusnya dilakukan dengan kekerasan, tetapi harus dilakukan dengan cara yang membuat anak dapat menghargai tujuan peraturan, bersedia mengubah perilaku yang salah dan merasa tanggung jawab memperbaiki perilaku, dan peraturan kelas yang diberikan seharusnya tidak hanya berupa percakapan lisan antara guru dan anak, melainkan dapat memberikan kegiatan berupa permainan dengan menggunakan media yang membantu anak untuk lebih mengenalkan perilaku disiplin dengan cara yang menyenangkan dan mudah diterima oleh anak. Sehingga anak juga dapat menumbuhkan perilaku disiplin. Oleh karena itu, guru memiliki peranan yang sangat penting untuk membuat media permainan atau suatu kegiatan khusus untuk menstimulasi kedisiplinan anak. Media yang disediakan merupakan salah satu hal yang dapat mempengaruhi kebiasaan perilaku anak. Diketahui bahwa anak usia dini sangat senang dengan hal yang unik dan menarik, untuk mempermudah kegiatan pembelajaran. Sehubungan dengan pernyataan tersebut maka dalam proses pembelajaran perilaku disiplin pada anak usia dini dapat dilakukan dengan memberikan kegiatan bermain menggunakan media yang mengedukasi sesuai dengan tujuan tersebut.

Berdasarkan hasil observasi di lapangan, peneliti menemukan masih banyaknya anak usia 4-5 tahun yang kurang disiplin dan bertanggung jawab di lingkungan sekitarnya terutama dikelas, seperti 1) setelah selesai belajar anak tidak meletakkan alat permainan sesuai pada tempatnya sehingga guru yang harus merapikannya , 2) tidak meletakkan tas dan sepatu dengan rapi pada tempatnya, 3) tidak merapikan kembali peralatan belajarnya, 4) tidak berpakaian lengkap,5) ketika mencuci tangan atau menyikat gigi setelah makan tidak mau mengantri, 6) sebelum makan tidak mau mencuci tangan dan berdoa.

Perilaku disiplin anak tumbuh baik dengan cara membiasakan peraturan di kelas. Peraturan kelas yang diberikan seharusnya tidak hanya berupa percakapan lisan antara guru dan anak, melainkan dapat memberikan kegiatan berupa permainan dengan menggunakan media yang membantu anak untuk lebih mengenalkan perilaku disiplin dengan cara yang menyenangkan dan mudah diterima oleh anak. Sehingga anak juga dapat menumbuhkan perilaku disiplin. Oleh karena itu, guru memiliki peranan yang sangat penting untuk membuat media permainan atau suatu kegiatan khusus untuk menstimulasi kedisiplinan anak.

Salah satu media yang dapat digunakan untuk mengenalkan perilaku disiplin pada anak usia 4-5 tahun adalah media permainan Koper Perilaku (KOPERKU). Media Koper Perilaku (KOPERKU) merupakan media yang dirancang oleh peneliti untuk mengenalkan, serta mengetahui kemampuan perilaku disiplin yang anak miliki dengan menggunakan flashcard atau kartu gambar seri yang terdiri dari tiga tahapan aktifitas yang kemudian nanti anak susun sesuai urutan, apabila urutan yang anak susun benar, maka lampu akan menyala dan suara sirine akan berbunyi dari koper yang menyimpan kartu gambar tersebut. Flashcard merupakan media pembelajaran dalam bentuk kartu gambar seri yang dapat menyampaikan suatu pesan kepada anak agar anak mampu menerima pesan dengan mudah dari alur cerita yang disediakan dan anak akan lebih senang untuk menerima. Menurut Sari dkk (dalam Eka dkk, 2019) kartu bergambar merupakan serangkaian gambar yang terpisah tetapi mempunyai jalan cerita yang searah atau sejalan.

Dengan Alat Permainan Edukatif (APE) media Koper Perilaku (KOPERKU) ini, diharapkan akan membuat anak menjadi tahu perilaku yang baik dan tidak baik, membuat kegiatan belajar anak lebih menyenangkan karena perilaku disiplin umumnya adalah suatu perintah yang keluar dari lisan guru sehingga menjadi pembiasaan bagi anak akan tetapi dengan media Koper Perilaku (KOPERKU) anak dapat mengikuti dan mengingat aturan dari ketentuan gambar yang ada pada media Koper Perilaku (KOPERKU) dan mengaplikasikannya dalam kehidupan nyata. Menurut Singer (dalam Dwi, 2018) bermain memberikan suatu cara untuk anak memajukan kecepatan masuknya perangsangan (stimulasi), baik dari luar maupun dari dalam yaitu aktifitas otak yang secara konstan memainkan kembali dan merekam pengalaman-pengalaman. Dengan mengenalkan kepada anak tentang perilaku disiplin melalui permainan media koper perilaku (KOPERKU) tentunya akan mudah di pahami dan di serap oleh anak karena suasana anak ketika bermain dengan perasaan yang menyenangkan sehingga juga dapat membantu anak belajar banyak hal tentang perilaku yang harus di biasakan anak sesuai norma-norma yang berlaku di lingkungannya.

Berdasarkan fenomena diatas, peneliti tertarik untuk meneliti tentang "Pengembangan Media Koper Perilaku (KOPERKU) Untuk Mengenalkan Perilaku Disiplin Anak Usia 4-5 Tahun”.

\section{METODE PENELITIAN}

Produk pengembangan media pembelajaran Koper Perilaku (KOPERKU) yang akan dikembangkan bertujuan untuk menghasilkan suatu produk alat permainan edukatif yang layak untuk anak usia 4-5 tahun. Produk media yang dikembangkan bertujuan untuk mengatasi permasalahan-permasalahan pembelajaran yang ada di kelas maupun di luar kelas. Oleh karena itu penelitian dilakukan menggunakan metode penelitian dan pengembangan atau dalam bahasa Inggris disebut Research and Development (R \& D) yaitu metode penelitian yang digunakan untuk menghasilkan produk tertentu dan menguji keefektifitasan produk tersebut. 
Berdasarkan prosedur dan pengembangan menurut Borg dan Gall dalam Sugiyono, peneliti hanya membatasi penelitiannya sampai revisi produk saja. Prosedur dan pengembangan yang digunakan oleh peneliti hanya potensi dan masalah, pengumpulan data, desain produk, validasi desain, revisi desain, uji coba produk, revisi produk.

Adapun langkah-langkah penelitian yang dilakukan adalah 1) potensi masalah, 2) pengumpulan data, 3) desain produk, 4) validasi produk, 5) revisi desain, dan 6) revisi produk.

Potensi adalah segala sesuatu yang dimanfaatkan akan menjadi nilai yang lebih. Menurut (Sugiyono, 2010) Potensi merupakan suatu yang apabila didayagunakan akan menjadi nilai tambah. Langkah awal peneliti yaitu dengan melakukan wawancara awal kepada guru kelas di Taman Kanak-Kanak Karnida Bahagia Kota Pekanbaru mengenai media alat pembelajaran edukatif (APE) yang digunakan untuk mengenalkan perilaku disiplin kepada anak, karena selama ini pembelajaran dalam hal mengenalkan perilaku disiplin adalah dengan mempraktikkannya secara langsung dan diketahui belum adanya media alat pembelajaran eduktif (APE) yang menarik untuk anak dalam hal memperkenalkan kepada anak perilaku disiplin secara menyenangkan.

Pengumpulan data awal untuk kaji pustaka, pengamatan kelas, identifikasi permasalahan dan merangkum permasalahan. Peneliti dalam penelitian ini mencari informasi dengan melakukan analisis terhadap kajian penelitian yang relevan mengenai media Koper Perilaku (KOPERKU) dan melakukan studi pustaka mengenai media Alat Permainan Edukatif (APE) yang digunakan dalam menanaman perilaku disiplin di Taman Kanak-Kanak.

Diwujudkan dalam bentuk gambar, sehingga dapat berguna sebagai pegangan untuk menilai dan membuat suatu produk. Selain itu juga harus disertakan dengan penjelasan mengenai bahan-bahan yang digunakan dalam setiap komponen, ukuran, alat dan prosedur kerja. Pada tahap ini, peneliti mengevaluasi fungsi media Koper Perilaku (KOPERKU) dan menyimpulkan hasil evaluasi media Koper Perilaku (KOPERKU) yang telah ada. Peneliti mendapatkan ide untuk mendesain dan mengembangkan media Koper Perilaku (KOPERKU) untuk mengenalkan perilaku disiplin anak usia 4-5 tahun.

Suatu proses kegiatan menilai rancangan produk yang bersifat penilaian berdasarkan pemikiran rasional atau belum fakta lapangan. Validasi dalam penelitian ini menghadirkan beberapa pakar atau tenaga ahli yang sudah berpengalaman untuk menilai produk baru yang dirancang tersebut. setiap pakar diminta untuk menilai desain media Koper Perilaku (KOPERKU) ini, sehingga dapat diketahui kelemahan dan kekurangannya. Kelemahan yang sudah diidentifikasikan tersebut kemudian direvisi agar menghasilkan produk yang diharapkan layak dan sesuai kebutuhan.

Kelemahan yang ada pada desain produk yang sudah didiskusikan dengan para ahli selanjutnya dicoba untuk memperbaiki desain oleh peneliti yang mau menghasilkan produk tersebut. peneliti melakukan perbaikan pada desain produk yang sudah dibuat berdasarkan masukan-masukan yang sudah diberikan oleh ahli media, ahli materi dan ahli pendidik.

Dari hasil coba produk, terdapat tanggapan yang kemudian dijadikan bahan revisi oleh peneliti dan selanjutnya Koper Perilaku (KOPERKU) dapat digunakan pada uji coba pemakaian dengan jumlah subjek yang lebih banyak.

Analisis data pada tahap identifikasi masalah tersebut menggunakan analisis deskriptif. Analisis data terhadap kualitas dan kelayakan produk melalui hasil penilaian dari ahli materi, ahli media dan ahli pendidik dengan menggunakan instrumen angket, serta analisis data dari uji kelayakan oleh anak didik menggunakan instrumen wawancara terbatas yang telah disediakan pertanyaan-pertanyaan tertulis. Teknik analisis data yang digunakan terhadap kualitas produk adalah analisis data deskriptif kuantitatif.

Teknik pengumpulan data pada validasi ahli menggunakan skala Likert dengan skala penilaian 1-4. Skala 1-4 memiliki penjelasan, angka 1) kurang baik, 2) cukup baik, 3) baik, dan 4) sangat baik. Kelayakan media Koper Perilaku (KOPERKU) dihasilkan melalui beberapa tahapan analisis dengan tahap 1) melakukan rekapitulasi data hasil penelitian. Merubah penilaian bentuk kualitatif menjadi kuantitatif menggunakan skala Likert dan 2) menghitung skor rata-rata dari instrumen dengan rumus sebagai berikut:

Keterangan:

$$
X=\left(\sum x\right) / n
$$

$$
\begin{array}{ll}
\mathrm{X} & =\text { Skor rata-rata } \\
\Sigma \mathrm{x} & =\text { jumlah skor } \\
\mathrm{n} & =\text { jumlah subjek uji coba }
\end{array}
$$

\section{HASIL DAN PEMBAHASAN}

Validasi ahli materi dilakukan dalam 1 tahap yang dilakukan oleh dua orang ahli materi yaitu ahli materi I dan ahli materi II, pada validasi materi yang dilakukan oleh ahli materi I, memperoleh penilaian dengan kategori "Valid" dengan perolehan rata-rata nilai 2,5 kemudian tahap validasi materi II, memperoleh penilaian dengan kategori "Valid" dengan perolehan rata-rata nilai 2,5 kemudian hasil validasi ahli materi I dan ahli materi II digabungkan dan memperoleh penilaian dengan kategori "Layak" dengan perolehan rata-rata nilai 
2,5. Pada Tahap ini validator ahli materi memberi komentar bahwa KD dan Indikator serta tujuan yang ingin dicapai kurang jelas.

Validasi ahli media dilakukan dalam 1 tahapyang dilakukan oleh dua orang ahli media yaitu ahli media I dan ahli media II, pada validasi media yang dilakukan oleh ahli media I, memperoleh penilaian dengan kategori "Valid" dengan perolehan rata-rata nilai 2,5. Kemudian tahap validasi media II, memperoleh penilaian dengan kategori "Valid" dengan perolehan rata-rata nilai 2,9 kemudian hasil validasi ahli media I dan ahli media II digabungkan dan memperoleh penilaian dengan kategori "Layak" dengan perolehan rata-rata nilai 2,7. Namun dengan revisi sesuai saran, yaitu Media Koper Perilaku (KOPERKU) akan mencapai apa? Apakah aspek kognitif? Afektif? Motorik? Perlu dibuat sinkronisasi media dengan tujuan yang ingin dicapai.

Validasi ahli pendidik dilakukan dalam 1 tahap yang dilakukan oleh lima orang ahli pendidik, pada validasi yang dilakukan oleh ahli pendidik I, memperoleh penilaian dengan kategori "Valid" dengan perolehan rata-rata nilai 3,1 pada validasi yang dilakukan oleh ahli pendidik II, memperoleh penilaian dengan kategori " Sangat Valid" dengan perolehan rata-rata nilai 3,4pada validasi yang dilakukan oleh ahli pendidik III, memperoleh penilaian dengan kategori "Sangat Valid" dengan perolehan rata-rata nilai 3,5 pada validasi yang dilakukan oleh ahli pendidik IV, memperoleh penilaian dengan kategori "Valid" dengan perolehan rata-rata nilai 3,1 pada validasi yang dilakukan oleh ahli pendidik $\mathrm{V}$, memperoleh penilaian dengan kategori " Sangat Valid" dengan perolehan rata-rata nilai 3,3 kemudian hasil validasi lima ahli pendidik digabungkan dan memperoleh penilaian dengan kategori "Layak" dengan perolehan rata-rata nilai 3,2.

Hasil nilai dari ketiga tahapan validasi ahli materi, ahli media, dan ahli pendidik selanjutnya digabungkan untuk mendapatkan hasil rata-rata nilai produk yang dikembangkan secara keseluruhan. Ratarata nilai validasi ahli materi, ahli media, dan ahli pendidik diperoleh jumlah rata-rata nilai keseluruhan yaitu 2,8 dengan kategori kelayakan "Layak" sehingga produk yang peneliti kembangkan layak untuk digunakan sebagai media untuk membantu anak mengenal perilaku disiplin yang baik dan benar.

Menurut Yunika, 2019 (dalam Ria, 2020) Anak usia dini yang berada pada rentang usia 0-6 tahun mengalami proses pertumbuhan dan perkembangan yang fundamental. Pola pertumbuhan dan perkembangan anak pada periode ini sangat mempengaruhi kondisi fisik dan mentalnya ketika dewasa nanti. Sedemikian pentingnya masa usia dini ini sehingga disebut pula dengan masa emas atau golden age.

Menurut Ria, dkk (2019) Anak generasi alpha berada pada usia keemasan karena pada masa ini perkembangan anak terjadi sangat pesat dan tidak bisa diulang kembali pada masa berikutnya. Aspek perkembangan kognitif, Bahasa, moral dan agama, fisik motorik dan sosial emosional yang terjadi pada usia ini akan menjadi dasar yang berpengaruh dan dapat menjadi penentu perkembangan anak pada saat remaja dan dewasa. Karena pentingnya masa-masa keemasan ini, maka akan sangat baik bila semua stimulasi yang diberikan pada anak memiliki dampak positif bagi perkembangannnya. Menurut Choirun (2013) Karakteristik perilaku disiplin anak usia 4-5 tahun yaitu anak mulai memahami adanya keterkaitan antara tingkah laku yang tidak baik dengan konsekuensi yang didapatkannya karena masing-masing anak mempunyai kelebihan dalam memahami aturan yang ada dilingkungan kehidupannya. Disiplin perlu untuk mempermudah anak menyesuaikan diri dengan kehidupan bersosial.

Mendisiplinkan anak dengan cara mengembangkan disiplin diri sendiri hal yang sangat penting dalam menerapkan disiplin pada anak untuk medisiplinkan mereka secara nyata. Cara orang tua mendisiplinkan anak dapat mengembangkan disiplin atau malah melemahkan harga diri, kontrol diri dan resiliensi. Salah satu tujuan utama penerapan disiplin adalah untuk menciptakan lingkungan yang aman, serta menumbuhkembangkan kontrol diri dan disiplin anak (Ria, 2020). Dengan demikian pendidik perlu bersungguh sungguh untuk mengajarkan anak terutama dalam hal berperilaku dengan baik. Karena perilaku yang baik merupakan hal yang paling utama harus ditanamkan kepada anak untuk meningkatkan hubungan sosial dan untuk mempersiapkan diri mereka ketika dewasa, saat mereka sangat bergantung kepada disiplin diri. Perilaku disiplin merupakan aturan, norma, serta patokan mengenai perilaku yang sesuai dengan ketentuan yang berlaku di masyarakat atau lingkungan dimana individu berada (Ahmad Susanto, 2018).

Dalam hal ini yang paling efektif untuk membantu anak berperilaku yang baik terutama dalam berperilaku disiplin adalah dengan memberi keteladanan dalam bersikap. Saat ini banyak orang tua mengandalkan tempat les, guru sekolah dan google untuk membantu anak- anak belajar. Namun hal ini jangan sampai menjadikan orang tua tidak bisa dijadikan tempat bertanya oleh anak, apabila hal tersebut terjadi orang tua akan kehilangan kesempatan untuk menjadi teladan bagi anak dan tidak mampu mempengaruhi anak untuk berperilaku baik (Ria, 2019).

Tidak hanya memberikan keteladanan, salah satu cara yang menarik untuk anak dapat mengenal perilaku disiplin dan menanamkan diri untuk disiplin dapat dilakukan oleh guru maupun orang tua adalah dengan menstimulasi anak selama masa pertumbuhan dan perkembangan yang sangat pesat dan hal ini akan sangat berarti bagi kehidupan anak dikemudian hari, menstimulasi anak agar lebih mudah untuk menerima dan menarik perhatian anak untuk belajar adalah dengan menyediakan media. Dalam kegiatan-kegiatan atau aktifitas yang dilakukan di sekolah, sering dijumpai banyak anak yang masih kurang disiplin disebabkan 
kurangnya media yang menarik perhatian anak untuk lebih tertarik untuk mengetahui perilaku disiplin yang baik dan menanamkan pentingnya perilaku disiplin dalam diri.

Menurut Talizaro (2018) media pembelajaran adalah suatu proses belajar dan mengajar yang memiliki kesatuan yang tidak bisa dipisahkan dalam dunia pendidikan. Seperti yang diketahui bahwa anak usia dini memiliki cara belajarnya sendiri, anak usia dini memperoleh pengalaman terbaik dalam perkembangan belajar melalui benda-benda menarik yang ada disekelilingnya sehingga mempermudah penyampaian dan penguatan kepada anak.

Pembelajaran yang berarti atau bermakna bagi anak terjadi ketika anak bermain, dalam hal ini anak dapat menyalurkan naluri keingintahuannya, memperkuat koordinasi motorik kasar dan halus, menggunakan kreativitas, meningkatkan keterampilan sosial dan keterampilan disiplin (Ria, 2015).

Dengan demikian media yang dikembangkan dalam penelitian ini yaitu Koper Perilaku (KOPERKU) yang bertujuan sebagai media alat permainan edukatif untuk anak usia 4-5 tahun dalam hal mengenal perilaku disiplin yang baik dan benar. Koper Perilaku (KOPERKU) berbahan dasar kayu. Di sisi lain, memiliki ketahanan yang kuat tidak mudah berubah bentuk, tidak terlalu tebal mempunyai banyak variasi sesuai keinginan, berbasis teknologi dan juga mudah untuk dibawa tempat manapun. Media ini berupa koper yang didalamnya terdapat beberapa kartu gambar berseri yang menampilkan gambar animasi anak dalam proses berperilaku disiplin. Penelitian ini menyajikan nilai-nilai karakter dasar yang penting untuk anak seperti disiplin, tanggung jawab dan kemandirian melalui kartu gambar berseri.

Media ini diharapkan mampu membantu anak untuk mengenal tentang proses perilaku disiplin yang baik dan benar dengan cara yang lebih menyenangkan. Karena media ini di desain dengan gambar lucu dan warna warni sehingga akan mampu menstimulus ingatan anak untuk menanamkan dalam dirinya perilaku disiplin sehingga membentuk karakter disiplin yang baik. Koper Perilaku (KOPERKU) menggunakan nilai-nilai yang berbentuk simbol berupa kartun yang dikhususkan untuk anak usia dini, hal ini sesuai dengan teori piaget bahwa anak usia 2-7 tahun pada tahap ini mulai bermain kreatif, sudah memiliki gambaran jiwa, mengenal dirinya, menggunakan simbol. Kegiatan dalam permaian media Koper Perilaku (KOPERKU) akan membantu anak berfikir, bermain kreatif karena menggunakan gambar. Menurut Akhmad (2006) media gambar seri dapat membantu anak dalam memahami isi gambar, menarik dan bervariasi, mudah disajikan karena kartu gambar berseri memiliki hubungan keruntunan peristiwa antar gambar satu dengan gambar yang lainnya sehingga menampilkan cerita yang membangun daya pikir anak.

Koper Perilaku (KOPERKU) mampu mendorong anak untuk mengembangkan kecerdasan jamak berupa visual spasial yaitu berfikir melalui gambar berupa simbol atau gambar disiplin. Karena pada media ini akan mengajak anak usia dini untuk berimajinasi, didukung dengan adanya gambar yang disesuaikan dengan anak usia dini dan memiliki warna yang beraneka ragam. Sehingga menjadikan media Koper Perilaku (KOPERKU) cocok mengenalkan perilaku disiplin anak usia 4-5 tahun.

Perilaku disiplin pada anak usia dini dapat dilihat dari beberapa proses, diantaranya yaitu 1) proses perhatian (pada tahap ini anak memainkan Koper Perilaku (KOPERKU) sekaligus akan memperhatikan gambar-gambar yang ada pada Koper Perilaku (KOPERKU), 2) proses penyimpanan dalam ingatan (setelah anak selesai memainkan media Koper Perilaku (KOPERKU) anak akan menyimpan makna, kesan dan pesan yang ada pada media permainan tersebut, proses penyimpanan selanjutnya akan dikelola oleh otak untuk kemudian menghasilkan sebuah perilaku disiplin), dan 3) proses motivasi (anak akan mulai melakukan perilaku disiplin sesuai dengan gambar yang terdapat pada media Koper Perilaku (KOPERKU).

Dengan adanya media Koper Perilaku (KOPERKU) ini, diharapkan akan membuat kegiatan belajar anak lebih menyenangkan karena perilaku disiplin umumnya adalah suatu perintah yang keluar dari ucapan guru sehingga menjadi pembiasaan bagi anak, tetapi dengan media Koper Perilaku (KOPERKU) anak dapat mengikuti dan mengingat aturan dari ketentuan gambar yang ada pada media Koper Perilaku (KOPERKU) dan mengaplikasikannya dalam kehidupan nyata karena media ini mampu menyampaikan suatu pesan kepada anak sehingga anak mampu menerima pesan dengan mudah dari alur cerita yang disediakan dan anak akan lebih senang untuk menerima.

Tujuan dari penelitian pengembangan ini adalah untuk menghasilkan Alat Permainan Edukatif (APE) media Koper Perilaku (KOPERKU) yang layak digunakan dalam proses pembelajaran anak usia 4-5 tahun. Kelayakan produk diperoleh dari data penilaian validator ahli materi dan ahli media. Dalam penelitian pengembangan media ini dilakukan beberapa tahap untuk mendapatkan penilaian dan saran agar produk yang dikembangkan sesuai dengan aspek perkembangan yang diharapkan. Adapun tahap dalam penelitian ini yaitu tahap validasi ahli materi, ahli media dan ahli pendidik.

Hasil nilai dari ketiga tahapan validasi ahli materi, ahli media dan ahli pendidik selanjutnya digabungkan untuk mendapatkan hasil rata-rata nilai produk yang dikembangkan secara keseluruhan. Ratarata nilai validasi dari ahli materi, ahli media dan ahli pendidik diperoleh jumlah rata-rata nilai keseluruhan yaitu 2,8 dengan kategori kelayakan "Layak" sehingga produk yang peneliti kembangkan layak untuk digunakan sebagai media untuk membantu anak mengenal perilaku disiplin yang baik dan benar. 
Tabel

Tabel 1. Perolehan Hasil Uji Coba Validasi Ahli Materi

\begin{tabular}{crrrr}
\hline Validasi ahli & Jumlah Skor & Rata-rata Skor & Kategori & \multicolumn{2}{c}{ Kelayakan } \\
\hline Ahli Materi & 25 & 2,5 & Valid & Layak \\
\hline Ahli Materill & 25 & 2,5 & Valid & Layak \\
\hline Kesimpulan & $\mathbf{5 0}$ & $\mathbf{2 , 5}$ & Valid & Layak \\
\hline
\end{tabular}

Tabel 2. Perolehan Hasil Uji Coba Validasi Ahli Materi

\begin{tabular}{ccccc}
\hline Validasi Ahli & Jumlah Skor & Rata-Rata Skor & Kategori & \multicolumn{2}{c}{ Kelayakan } \\
\hline Ahli Media I & 28 & 2,5 & Valid & Layak \\
\hline Ahli Media II & 32 & 2,9 & Valid & Layak \\
\hline Kesimpulan & 60 & 2,7 & Valid & Layak \\
\hline
\end{tabular}

Tabel 3. Perolehan Hasil Uji Coba Validasi Ahli Materi

\begin{tabular}{ccccc}
\hline Validasi Ahli & Jumlah Skor & Rata-Rata Skor & Kategori & Kelayakan \\
\hline Ahli Pendidik I & 67 & 3,1 & Valid & Layak \\
\hline Ahli Pendidik II & 72 & 3,4 & Sangat Valid & Layak \\
\hline Ahli Pendidik III & 75 & 3,5 & Sangat Valid & Layak \\
\hline Ahli Pendidik IV & 66 & 3,1 & Valid & Layak \\
\hline Ahli Pendidik V & 70 & 3,3 & Sangat Valid & Layak \\
\hline Kesimpulan & 350 & 3,2 & Sangat Valid & Layak \\
\hline
\end{tabular}

Tabel 4. Perolehan Hasil Uji Coba Validasi Ahli Materi

\begin{tabular}{ccccc}
\hline Validasi Ahli & Jumlah Skor & Rata-Rata Skor & Kategori & Kelayakan \\
\hline Ahli Materi & 50 & 2,5 & Valid & Layak \\
\hline Ahli Media & 60 & 2,7 & Valid & Layak \\
\hline Ahli Pendidik & 350 & 3,2 & Sangat Valid & Layak \\
\hline Kesimpulan & 460 & $\mathbf{2 , 8}$ & Valid & Layak \\
\hline
\end{tabular}

\section{Gambar}

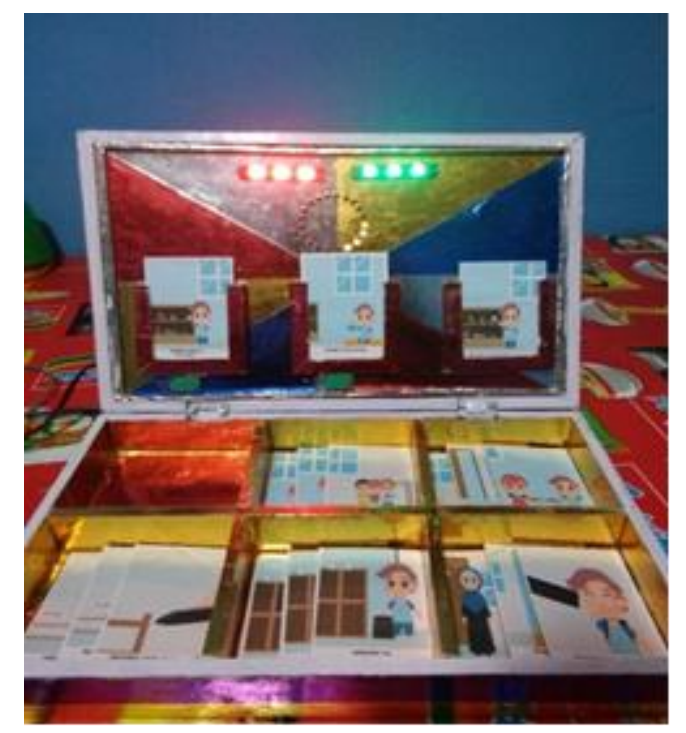

Gambar 1. Media Koper Perilaku (KOPERKU)

\section{SIMPULAN}

Alat permainan edukatif yang dikembangkan melalui media ini adalah Koper Perilaku (KOPERKU). Pengembangan Media Koper Perilaku (KOPERKU) dihasilkan dengan menggunakan tahapan model Bord and Gall dengan langkah-langkah diantaranya yaitu potensi dan masalah, pengumpulan data, desain produk, validasi desain, revisi desain, uji coba produk, revisi produk. Media koper perilaku (KOPERKU) bertujuan untuk ranah afektif anak dalam hal mengenal perilaku disiplin sesuai urutan dengan baik dan benar sehingga anak dapat mengikuti dan mengingat aturan secara menyenangkan dari ketentuan gambar yang ada pada media Koper Perilaku (KOPERKU) dan dapat mengaplikasikannya dalam kehidupan nyata. Koper Perilaku (KOPERKU) merupakan media yang dirancang untuk mengenalkan kepada anak usia 4-5 tahun mengenai perilaku disiplin dengan menggunakan flashcard atau kartu gambar seri yang terdiri dari tiga tahapan aktifitas yang kemudian nanti anak susun sesuai urutan, apabila urutan yang anak susun benar, maka lampu akan 
menyala dari koper dan ada suara yang akan berbunyi dari koper yang menyimpan kartu gambar tersebut. Flashcard merupakan media pembelajaran dalam bentuk kartu gambar seri yang dapat menyampaikan suatu pesan kepada anak agar anak mampu menerima pesan dengan mudah dari alur cerita yang disediakan. Media ini dinyatakan "Layak" oleh validator ahli materi, validator ahli media dan validator ahli pendidik dengan serangkaian uji validasi sehingga media layak untuk mengenalkan perilaku disiplin pada anak usia 4-5 tahun.

\section{UCAPAN TERIMA KASIH}

Dalam menyusun skripsi ini tentunya banyak ditemukannya hambatan serta rintangan yang penulis hadapi. Namun penulis dapat melalui semuanya berkat adanya bimbingan serta dukungan dari berbagai pihak baik secara formal maupun secara spiritual melalui doa. Untuk itu, pada kesempatan ini penulis ingin mengucapkan terimakasih kepada 1) Prof. Dr. Mahdum, M.Pd selaku dekan Fakultas Keguruan dan IImu Pendidikan Universitas Riau, 2) Ria Novianti, S.Psi, M.Pd selaku ketua jurusan IImu Pendidikan FKIP Universitas Riau yang telah membantu melancarkan penyusunan skripsi, 3) Enda Puspitasari, M.Pd selaku koordinator Program Studi Pendidikan Guru Pendidikan Anak Usia Dini Fakultas Keguruan dan IImu Pendidikan Universitas Riau, 4) Hukmi, S.Sn, M.Hum selaku dosen pembimbing akademis, 6) Hukmi, S.Sn, M.Hum dan Ria Novianti,S.Pd, M.Pd selaku dosen pembimbing I dan dosen pembimbing II yang telah bersedia meluangkan waktu untuk memberikan bimbingan dan arahan selama penyusunan skripsi, 7) Dr. Rita Kurnia, M. Ed dan Drs. Zulkifli N, M.Pd selaku validator ahli materi dan ahli media yang telah bersedia meluangkan waktu untuk mengisi angket penilaian produk dalam penelitian ini, 8) Yulzawati, S.Pd., Sri Hartuti Husin, S.Pd., Desi Saswita, S.Pd., Yenni Herwati, S.Pd., Herawati, S.Pd. selaku validator ahli pendidik yang telah bersedia meluangkan waktu untuk mengisi angket penilaian produk dalam penelitian ini, 9 Seluruh jajaran Dosen dan Staf Program Studi Pendidikan Guru Pendidikan Anak Usia Dini, 10) Keluarga tercinta Bunda Israhayati, Ayah Aprizal, dan Adik Muhammad Dendhi Wibawa yang telah memberi dukungan dan doa selama penyusunan skripsi ini, 11) Sahabat-sahabatku semua Nova Rosvika, Ines Permatasari Tarigan, Risqa Fina Fauziah, Novi Eka, Sri Wulandari, Desti Helfianti, Depi Afriani, Dwi silviani Okmandar, Silvi Mayasari, Yonara Rivalia, Yulia Herdin, Desi Sri Lestari dan Relwi Yani yang telah membantu serta memberikan dukungan selama proses pembuatan skripsi dan 12) Teman-teman seperjuangan dari jurusan Pendidikan Guru Pendidikan Anak Usia Dini serta semua pihak yang tidak dapat disebutkan satu persatu yang telah membantu memberikan dukungan.

\section{DAFTAR PUSTAKA}

Ahmad Susanto. 2018. Bimbingan Dan Konseling Di Sekolah. PRENADAMEDIA GROUP. Jakarta.

Amna Emda. 2017. Kedudukan Motivasi Belajar Siswa Dalam Pembelajaran. Fakultas Tarbiyah Dan Keguruan UIN Ar-Raniry Banda Aceh. 5(2). 174.

Akhmad Muhaimin Azzet. 2006. Urgensi Pendidikan Karakter di Indonesia. AR-RUZZ MEDIA. Yogyakarta.

Choirun Nisak Aulina. 2013. Penanaman Disiplin Pada Anak Usia Dini. Dosen Jurusan PG PAUD Fakultas Keguruan dan Ilmu Pendidikan Universitas Muhammadiyah Sidoarjo. 2(1). 37. http://ojs.umsida.ac.id/index.php/pedagogia/article/view/45

Dwi Kusuma Ningrum. 2018. Upaya Meningkatkan Perilaku Disiplin Anak Usia 4-5 tahun Melalui Permainan Ular Tangga Bercerita. Fakultas Ilmu Pendidikan. Universitas Negeri Jakarta. Jakarta.

Eka Pratiwi, Nurbiana Dhieni, Asep Supena.2019. Urgensi Media Cerita Gambar Berseri dalam Menstimulasi Perilaku Disiplin Anak Usia Dini. Universitas Negeri Jakarta. Jakarta. Journal Of Islamic Education 3(2). 173.

Iriani Indri Hapsari. 2016. Psikologi Perkembangan Anak. Indeks. Jakarta Barat.

Ria Novianti, Hukmi, Ilga Maria. 2019. Generasi Alpha-Tumbuh dengan Gadget dalam genggaman. Prodi PG PAUD FKIP Universitas Riau. EDUCHILD. 8(2). 66.

Ria Novianti. 2015. Pengembangan Permainan Roda Putar Untuk Meningkatkan Kemampuan Berhitung Angka Anak Usia 5-6 Tahun. Prodi PG PAUD FKIP Universitas Riau. EDUCHILD. 4(1). 56.

Ria Novianti. 2019. Paren-Team. Stiletto Indie Book. Yogyakarta.

Ria Novianti, Ilga Maria. 2020. Pendidikan Keorangtuaan. Ellunar Publisher. Yogyakarta.

Ria Novianti, Febrialismanto, Enda Puspitasari, Hukmi. 2020. Meningkatkan Pengetahuan Orang Tua Dalam Mendidik Anak Di Era Digital Di Kecamatan Koto Gasib Kabupaten Siak Provinsi Riau. Riau Journal Empowerment. 3(3). 184.

Sugiyono. 2010. Metode Penelitian Pendidikan. Alfabeta. Bandung.

Talizaro Tafunao. 2018. Peran Media Pelajaran dalam Meningkatkan Minat Belajar Mahasiswa. Jurnal Komunikasi Pendidikan, 2(2). 103.

Wantah M.J. 2005. Pengembangan disiplin dan pembentukan moral pada anak usia dini. Departemen Pendidikan Nasional, Direktorat Jendral Pendidikan Tinggi, Direktorat Pembinaan Tenaga Kependidikan Dan Ketenagaan Perguruan Tinggi. Jakarta. 